\title{
Originals
}

\section{Influence of Glucagon on Plasma Levels of Potassium in Man}

\author{
F. Massara, S. Martelli, E. Cagliero, F. Camanni, and G. M. Molinatti \\ Cattedra di Endocrinologia dell'Università di Torino, Torino, Italy
}

Summary. To investigate the role played by glucagon in the regulation of plasma potassium, we have examined the behaviour of this ion during four $2 \mathrm{~h}$ infusions of saline, glucagon $(200 \mathrm{ng} / \mathrm{min})$, cyclic somatostatin (priming dose of $50 \mu \mathrm{g}$ followed by $5.8 \mu \mathrm{g} / \mathrm{min}$ ) and somatostatin plus glucagon in 6 normal volunteers. Glucagon alone produced no change in potassium, despite an increase in insulin. Somatostatin, in addition to depressing insulin, produced a slight but significant $(\mathrm{p}<0.01)$ increase in potassium ( $\Delta$ max: $0.2-0.8 \mathrm{mmol} / \mathrm{l}$ : mean $\pm \mathrm{SEM}, 0.4 \pm 0.1$ ). Infusion of somatostatin together with glucagon suppressed the glucagon-induced increase in insulin and greatly augmented the increase in blood glucose. Potassium rose significantly more $(p<0.02)$ than after somatostatin alone ( $\Delta \max : 0.5-1.3 \mathrm{mmol} / \mathrm{l}$; mean $0.9 \pm 0.1$ ), indicating that hyperkalaemia results from hyperglucagonaemia in the absence of insulin. Evidence is presented that this last phenomenon is not mediated by hyperglycaemia or by a reduction in aldosterone secretion. It is suggested that low blood insulin and increased glucagon could be one of the mechanisms that underlie or magnify the hyperkalaemia observed in cases of serious stress or decompensated diabetes.

Key words: Potassium, glucagon, insulin, hyperkalaemia, somatostatin.

It is now accepted that insulin is one of the hormones responsible for regulating the level of plasma potassium; potassium values fall and rise, in response to an increase [1-2] and a decrease [3] in blood insulin.

Little is known, however, about the role of glucagon in the homeostasis of potassium, insofar as it has been difficult to discriminate, in vivo, between direct effects of glucagon and changes mediated by the increased insulin secretion that accompanies glucagon administration. The availability of somatostatin, a potent inhibitor of insulin and glucagon secretion
[4-5], offers the opportunity to dissect the respective role of the two hormones on potassium homeostasis.

We have studied the effect of an infusion of glucagon plus somatostatin on plasma potassium in normal subjects and compared the results to those observed in the same subjects during infusion of glucagon alone, somatostatin alone and saline alone. The possible contributions of other factors, such as hyperglycaemia and plasma aldosterone were also evaluated.

\section{Materials and Methods}

Four male and five female normal volunteers aged 24-30 years were studied following an overnight fast. All but one were within $10 \%$ of ideal body weight (mean $64 \mathrm{~kg}$, range $46-80 \mathrm{~kg}$ ). One subject was slightly obese $(90.5 \mathrm{~kg},+27 \%)$.

None of the subjects were taking any drugs at the time of study. Informed consent was obtained from all subjects. A 19 gauge butterfly needle was inserted in a vein in each arm, one for the infusion of drugs, the other for blood withdrawal. The IV lines were kept patent by a very slow infusion of $0.154 \mathrm{~mol} / \mathrm{l}$ saline.

Subjects rested on a bed and testing was not initiated until $30 \mathrm{~min}$ after insertion of IV needles. All test materials were administered by means of peristaltic pump. On successive days, and in random order, six subjects ( 4 males and 2 females) received four $2 \mathrm{~h}$ infusions of:

a) saline $(0.154 \mathrm{~mol} / \mathrm{l})(1 \mathrm{ml} / \mathrm{min})$

b) cyclic somatostatin (Serono, Rome) diluted in $0.154 \mathrm{~mol} / 1$ saline; priming dose of $50 \mu \mathrm{g}$, followed by $5.8 \mu \mathrm{g} / \mathrm{min}$.

c) glucagon diluted in $0.154 \mathrm{~mol} / \mathrm{l}$ saline $(200 \mathrm{ng} / \mathrm{min})$

d) somatostatin + glucagon in saline.

To ascertain the role of hyperglycaemia per se on plasma potassium changes, five of the subjects also underwent a fifth test, in which $1 \mathrm{ml} / \mathrm{min}$ of a $40 \mathrm{~g} / 100 \mathrm{ml}$ glucose solution was infused with somatostatin as in (b). The contribution of insulinopaenia to the effects of glucagon and somatostatin on plasma potassium was assessed by replacing insulin ( $20 \mathrm{mU} / \mathrm{min}$ Actrapid, Novo) during the glucagon + somatostatin infusion in two subjects. In all these experiments blood was withdrawn without stasis for the determination of plasma glucose, insulin, and potassium at $-30,-15,0$ (start of infusion), $+30,+45,+60,+75,+90,+105$ and $+120 \mathrm{~min}$.

To evaluate the behaviour of plasma aldosterone (PA) and renin activity (PRA) during the experimental procedures, three additional male subjects were studied with protocol c) and d). Blood was obtained at $-30,0,+30,+60,+90$ and $+120 \mathrm{~min}$. 

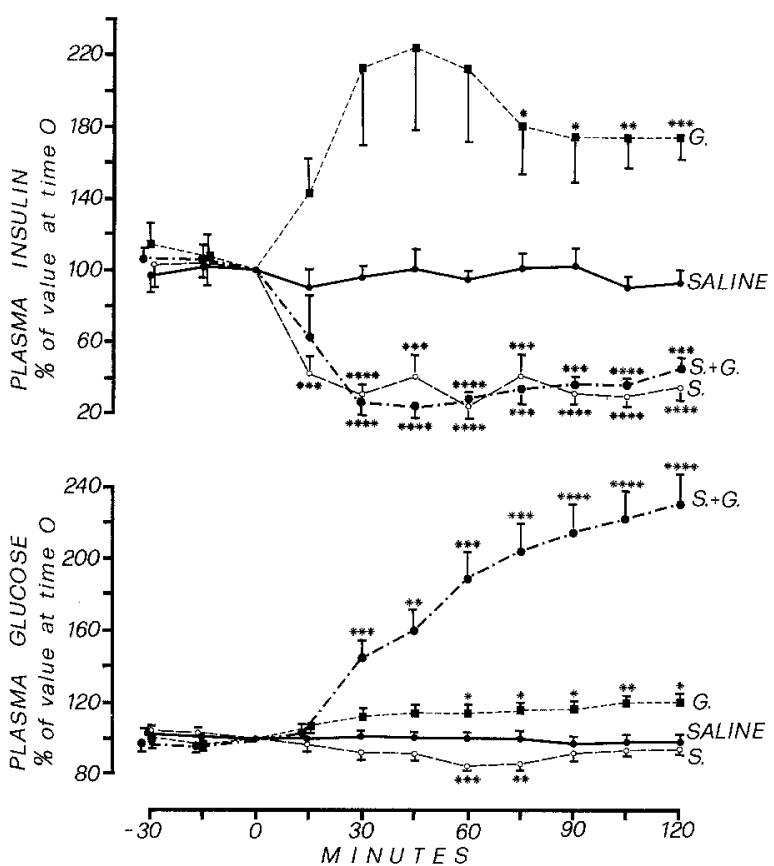

Fig. 1. Effect of infusion of saline, glucagon (G), somatostatin (S), somatostatin plus glucagon $(S+G)$ on the plasma insulin and glucose in six normal subjects. G: $200 \mu \mathrm{g} / \mathrm{min}$, S: priming dose of $50 \mu \mathrm{g}$ followed by $5.8 \mu \mathrm{g} / \mathrm{min}$. Vertical bar $=\mathrm{SEM}$. The significant differences from 0 time values are shown by: ${ }^{*} \mathrm{p}<0.05$, $* * \mathrm{p}<$ 0.02 , $* * \mathrm{p}<0.01,{ }^{*} * * * \mathrm{p}<0.001$. Absolute 0 time values were: Glucose $(\mathrm{mg} / \mathrm{dl})$ : saline $85 \pm 3$; S $86 \pm 3 ; \mathrm{G} 92 \pm 3$; $\mathrm{S}+\mathrm{G} 94 \pm$ 5. Insulin (mU/1): saline $7.3 \pm 0.9 ; \mathrm{S} 8.0 \pm 1.0 ; \mathrm{G} 6.8 \pm 1.0 ; \mathrm{S}+$ $\mathrm{G} 7.5 \pm 1.8$

Table 1. Plasma potassium in six normal subjects during infusion of saline $(0.154 \mathrm{~mol} / 1)$ glucagon $(200 \mathrm{ng} / \mathrm{min})$, somatostatin (bolus $50 \mu \mathrm{g}+5.8 \mu \mathrm{g} / \mathrm{min}$ ) and somatostatin plus glucagon. Results in $\mathrm{mmol} / \mathrm{l}$, mean $\pm \mathrm{SEM}$

\begin{tabular}{llllll}
\hline Time, min & 0 & 30 & 60 & 90 & 120 \\
\hline Saline & 3.9 & 4.1 & 4.1 & 4.0 & 4.0 \\
& 0.1 & 0.1 & 0.1 & 0.1 & 0.1 \\
Glucagon & 3.9 & 4.0 & 4.1 & 4.1 & 4.1 \\
& 0.1 & 0.1 & 0.1 & 0.1 & 0.1 \\
Somatostatin & 3.8 & 3.9 & $4.1^{\mathrm{b}}$ & $4.2^{\mathrm{b}}$ & $4.2^{\mathrm{b}}$ \\
& 0.1 & 0.1 & $0.1^{\mathrm{b}}$ & 0.1 & $0.1^{\mathrm{b}}$ \\
Somatostatin + & 3.9 & $4.2^{\mathrm{a}}$ & $4.3^{\mathrm{b}}$ & $4.5^{\mathrm{b}}$ & $4.7^{\mathrm{b}}$ \\
glucagon & 0.1 & 0.1 & $0.2^{2}$ & 0.2 & 0.2 \\
\hline
\end{tabular}

${ }^{\mathrm{a}} \mathrm{p}<0.05$ vs value at time $0,{ }^{\mathrm{b}} \mathrm{p}<0.01$ vs value at time 0

Blood for the determination of insulin and glucose $(4 \mathrm{ml}$ with $0.05 \mathrm{ml}$ of saturated EDTA solution), glucagon ( $4 \mathrm{ml}$ with EDTA and aprotinin $500 \mathrm{KIE} / \mathrm{ml}$ ), potassium, renin and aldosterone $(6-7 \mathrm{ml}$ with a drop of heparin) were collected in refrigerated tubes and immediately centrifuged to separate the plasma.

Plasma glucose was measured by the glucose oxidase method employing a Beckman analyzer, potassium by flame photometry with lithium as the internal standard (flame photometer, I. L. Mod 343), insulin, aldosterone, renin (Kits: CEA IRE SORIN, Saluggia, Italy) $[6,7,8]$ and pancreatic glucagon (antibody R 78, Glucagon-Peg Kit, Biodata) by a single antibody radioimmunoassay. The intra and interassay coefficients of variation were: potassium $0.5 \%$ and $4 \%$, glucagon $9 \%$ and $16 \%$, insulin $4 \%$ and $8 \%$, aldosterone $8 \%$ and $12 \%$, renin $8 \%$ and $18 \%$.
Statistical analysis was carried out by the paired Student $t$-test. The results are presented as mean $\pm \mathrm{SEM}$.

\section{Results}

No significant changes in blood glucose, insulin, and potassium were noted during the control infusion with saline (Figs. 1 and 2, Table 1). Infusion of glucagon alone led to a slight, but significant increase in glucose and insulin (Fig. 1). In spite of the increase in insulin plasma potassium did not decrease (Fig. 2). Somatostatin alone caused a small significant decrease in glucose (nadir at $60-75 \mathrm{~min}$ ) followed by a return to baseline, and a rapid fall in insulin to values significantly lower than baseline which were mantained throughout the infusion (Fig. 1). Potassium values progressively rose to a plateau at 75-120 min (Table 1, Fig. 2). This increase was statistically significant from +45 min onwards and the maximum increase of $0.4 \pm 0.1 \mathrm{mmol} / 1$ was highly significant $(\mathrm{p}<0.01)$.

The administration of glucagon together with somatostatin magnified the rise in plasma potassium (Table 1, Fig. 2). The maximum increment of $0.9 \pm$ $0.1 \mathrm{mmol} / \mathrm{l}$ was significantly higher $(\mathrm{p}<0.02)$ than that induced by somatostatin alone. Plasma glucose progressively rose from $94 \pm 5$ to $212 \pm 9 \mathrm{mg} / \mathrm{dl}$ at the end of the combined glucagon and somatostatin infusion. As shown in Table 2 the infusions with glucagon induced an increase in plasma levels of this hormone in the high physiological range. To determine a possible role of hyperglycaemia distinct from the glucagon effect somatostatin was infused together with glucose to obtain a rise in blood glucose comparable to the one observed in the glucagon + somatostatin test. It can be seen in Figure 3, that the increase in plasma glucose and the fall in insulin were comparable with those noted in the somatostatin + glucagon studies, whereas the rise in potassium was significantly lower than that induced by glucagon, and similar to that brought about by somatostatin alone.

In two subjects the somatostatin + glucagon test was repeated with the addition of $20 \mathrm{mU} / \mathrm{min}$ of insulin. The increases in plasma potassium and glucose induced by the combination of glucagon and somatostatin, were markedly reduced by the addition of this replacement dose of insulin. This dose induced an increase of plasma insulin (about $+150 \%$, with peaks of 10 and $12 \mathrm{mU} / \mathrm{l}$ ) similar to that observed after glucagon alone.

Table 2 illustrates the behaviour of plasma glucagon, renin and aldosterone in 3 subjects during the infusions with glucagon and glucagon plus somatostatin. Plasma glucagon reached levels that were not significantly different in the two tests. Renin and aldosterone did not change significantly in either experiment. 


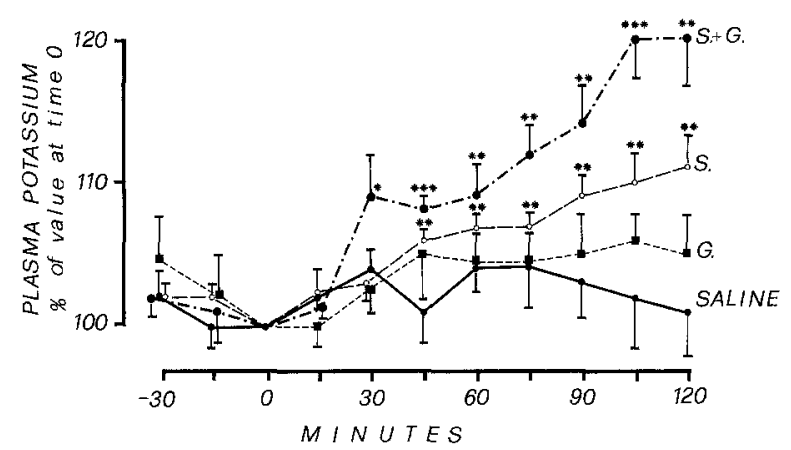

Fig. 2. Plasma potassium before and after infusion of saline, glucagon $(\mathrm{G})$, somatostatin (S), somatostatin plus glucagon $(S+G)$ in six normal subjects. Significant differences from 0 time values are shown by: ${ }^{*} \mathrm{p}<0.02,{ }^{* *} \mathrm{p}<0.01,{ }^{* * *} \mathrm{p}<0.001$. Absolute values are given in Table 1

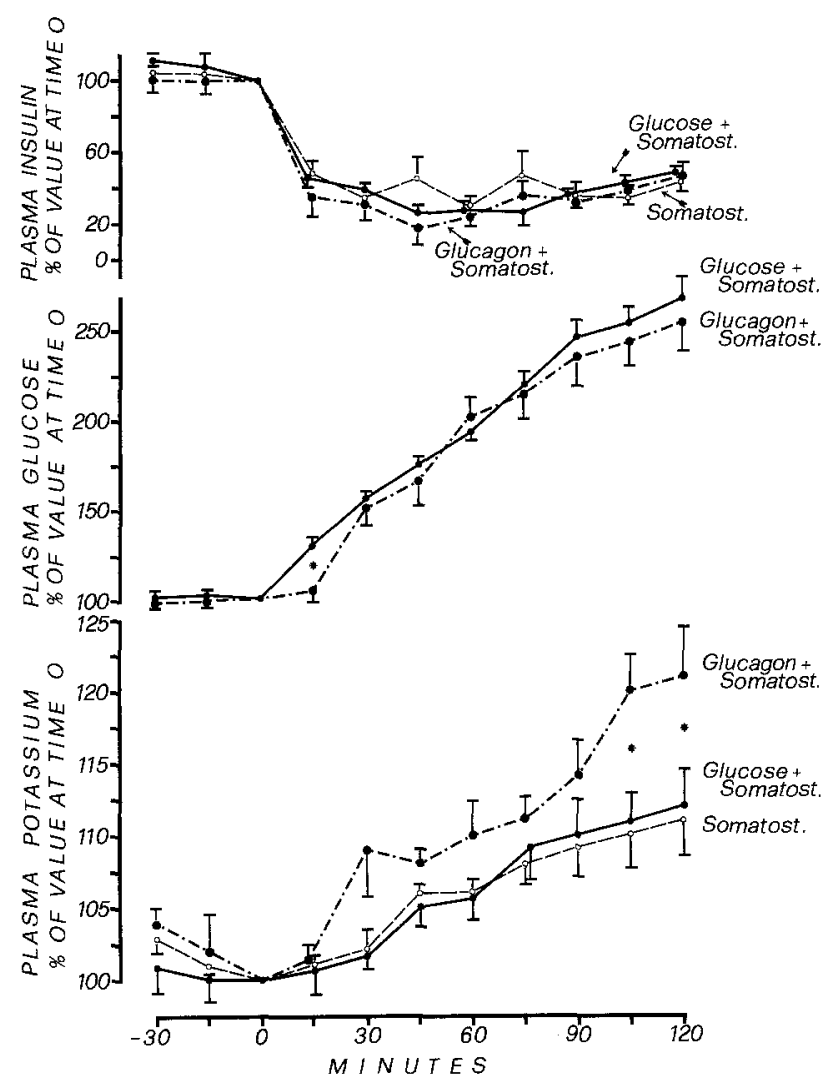

Fig. 3. Plasma potassium, glucose and insulin during infusion with somatostatin, somatostatin plus glucagon and somatostatin plus glucose solution in 5 subjects. ${ }^{*} \mathrm{p}<0.05$ between glucagon plus somatostatin and somatostatin with or without glucose

\section{Discussion}

The present data agree with those of De Fronzo et al. [3] in demonstrating that administration of somatostatin induces a slight but significant rise in plasma potassium. In addition, this study provides evidence that physiological levels of glucagon magnify the effects of insulin deficiency on plasma potassium con-
Table 2. Plasma renin activity, aldosterone, glucagon and potassium (mean $\pm S E M$ ) before and during infusion of glucagon and glucagon plus somatostatin in three normal volunteers. Values as mean $\pm \mathrm{SEM}$

\begin{tabular}{lcccccc}
\hline Time, min & -30 & 0 & +30 & +60 & +90 & +120 \\
\hline Glucagon & & & & & & \\
Renin & 1.9 & 2.2 & 2.0 & 2.0 & 2.0 & 1.8 \\
ng angiotensin $\mathrm{I} / \mathrm{ml} / \mathrm{h}$ & 0.2 & 0.3 & 0.2 & 0.1 & 0.2 & 0.1 \\
Aldosterone & 65 & 65 & 70 & 72 & 70 & 68 \\
$\mathrm{pg} / \mathrm{ml}$ & 13 & 12 & 11 & 12 & 8 & 6 \\
Glucagon & 63 & 71 & $273^{\mathrm{a}}$ & $278^{\mathrm{a}}$ & $261^{\mathrm{a}}$ & $258^{\mathrm{a}}$ \\
$\mathrm{pg} / \mathrm{ml}$ & 12 & 10 & 26 & 31 & 24 & 37 \\
Potassium & 3.7 & 4.0 & 4.0 & 4.0 & 4.0 & 4.0 \\
mmol/l & 0.1 & 0.1 & 0.1 & 0.1 & 0.1 & 0.1 \\
\hline Glucagon + Somatostatin & & & & & \\
Renin & 2.0 & 1.9 & 1.9 & 2.0 & 2.0 & 1.9 \\
ng angiotensin $\mathrm{I} / \mathrm{ml} / \mathrm{h}$ & 0.1 & 0.1 & 0.1 & 0.1 & 0.1 & 0.1 \\
Aldosterone & 67 & 67 & 63 & 67 & 73 & 93 \\
pg/ml & 9 & 7 & 9 & 4 & 9 & 12 \\
Glucagon & 73 & 62 & $270^{\mathrm{a}}$ & $280^{\mathrm{a}}$ & $225^{\mathrm{a}}$ & $253^{\mathrm{a}}$ \\
$\mathrm{pg} / \mathrm{ml}$ & 12 & 3 & 18 & 27 & 24 & 12 \\
Potassium & 4.0 & 3.8 & 4.0 & 4.3 & 4.4 & $4.7^{\mathrm{a}}$ \\
mmol/l & 0.1 & 0.1 & 0.2 & 0.1 & 0.1 & 0.1 \\
\hline
\end{tabular}

${ }^{\mathrm{a}} \mathrm{p}<0.05$ vs the values at time 0

centration since replacement of glucagon during somatostatin infusion resulted in a significantly higher potassium rise than that observed during combined deficiency of both hormones.

The increment in plasma potassium observed during administration of somatostatin is most likely mediated by the acute suppression of insulin secretion since it could be abolished by replacement of basal insulin levels and was not observed in insulin deficient diabetic patients [3]. Furthermore the administration of somatostatin has been shown to mimic the effects of pancreatectomy in impairing the removal of an exogenous load of potassium from extracellular fluid in the dog $[3,9]$. These data can be taken to indicate that basal plasma insulin is one of the factors regulating the passage of potassium into cells.

The augmentation in potassium rises seen during glucagon administration cannot be attributed to the concomitant hyperglycaemia $[10,11]$. Hyperglycaemia induced by glucose administration in presence of somatostatin resulted in increments in plasma potassium well below those induced by somatostatin plus glucagon. Although it had already been reported [12] that somatostatin, at doses larger than those used in this study, had no suppressive effect on aldosterone secretion it seemed crucial to exclude a role for a decrease in aldosterone levels in the rise in plasma potassium observed during somatostatin and glucagon + somatostatin infusions. 
Neither plasma renin activity nor aldosterone levels were significantly affected by the doses of somatostatin and glucagon which induced a significant rise in plasma potassium.

Glucagon has been observed to have an antimineralocorticoid action in both fasting and fed subjects $[13,14]$. However, this action is probably only manifested with an increase in urinary sodium excretion, since urinary potassium concentrations in the above studies were not altered by circulating levels of glucagon markedly higher than the ones achieved in our study.

Other authors have even reported a kaliuretic effect of high doses of glucagon $[15,16]$ although circulating levels of glucagon comparable to ours have been shown to have no effect on renal excretion of potassium $[3,17]$. The mechanism by which glucagon exacerbates hyperkalaemia in the insulin deficient state remains undefined. Data obtained from animals experiments [18] and "in vitro" perfusion of rat liver $[19,20]$ suggest that glucagon might increase the flow of potassium from the liver, at least in part as a result of glycogenolysis $[19,20]$. The plasma levels of glucagon that we have found associated with a significant increase in plasma potassium are well within the range described in physiological situations, such as protein meals and fasting [21, 22], and diseases such as decompensated diabetes [23], cirrhosis [24] and uraemia [25]. It is conceivable that in the above situations, and in particular when insulin deficiency in also part of the picture, circulating glucagon might represent a contributory factor to the derangement in potassium homeostasis.

Acknowledgements. The Authors wish to thank Serono (Rome) for the supply of cyclic somatostatin, and Mr. M. Rotunno, Mrs. L. Scaravelli and V. Giacone for their excellent technical assistance. The Authors wish also to express their gratitude to Dr. Mara Lorenzi (Metabolic Research Unit, University of California, San Francisco) for her helpful criticism and suggestions in the preparation of the manuscript.

\section{References}

1. Harrop Jr GA, Benedict EM (1923) The role of phosphate and potassium in carbohydrate metabolism following insulin administration. Proc Soc Exp Biol Med 20: 430-435

2. Andres R, Baltzan MA, Cader G, Zierler KL (1962) Effect of insulin on carbohydrate metabolism and on potassium in the forearm of man. J Clin Invest 41: 108-115

3. De Fronzo RA, Sherwin RS, Dillingham M, Hendler R, Tamborlane WV, Felig P (1978) Influence of basal insulin and glucagon secretion on potassium and sodium metabolism. Studies with somatostatin in normal dogs and in normal and diabetic human beings. J Clin Invest 61: 472-479

4. Gerich JE, Lorenzi M, Schneider V, Forsham PH (1974) Effects of somatostatin on plasma glucose and insulin responses to glucagon and tolbutamide in man. J Clin Endocrinol Metab 33: 1057-1060

5. Massara F, Porzio G, Camanni F, Molinatti GM (1975) The effect of somatostatin on plasma insulin and growth hormone levels in basal conditions and after glucagon in normal and acromegalic subjects. Acta Diabetol Lat 12: 219-231

6. Malvano R, Zucchelli GC, Quesada T, Gandolfi C, Piro AM (1974) Insulin radioimmunoassay: a comparison of three methods. J Nucl Biol Med 18: 80-86

7. Malvano R, Gandolfi C, Giannessi D, Gianotti P, Grosso P (1976) Radioimmunoassay of aldosterone on crude plasma extract. J Nucl Biol Med 20: 37-44

8. Malvano R, Zucchelli GC, Rosa U, Salvetti A (1972) Measurement of plasma renin activity by angiotensin $I$ radioimmunoassay: I) An assessement of some methodological aspects. J Nucl Med Allied Sci 16: 24-31

9. Hiatt N, Morgenstern L, Davidson MB, Bonorris G, Miller A (1973) Role of insulin in the transfer of infused potassium to tissue. Horm Metab Res 5: 84-88

10. Perez GO, Lespier L, Knowles R, Oster JR, Vaamonde CA (1977) Potassium homeostasis in chronic diabetes mellitus. Arch Intern Med 137: 1018-1022

11. Viberti GC (1978) Glucose-induced hyperkalaemia: a hazard for diabetics? Lancet I: 690-691

12. Gomez-Pan A, Snow MM, Piercy DA, Robson V, Wilkinson R, Hall R, Evered DC (1976) Actions of growth hormone releasing inhibiting hormone (somatostatin) on the renin aldosterone system. J Clin Endocrinol Metab 43: 240-243

13. Sudeck CD, Boultier PR, Arky RA (1973) The natriuretic effect of glucagon and its role in starvation. J Clin Endocrinol Metab 36: 761-765

14. O'Brian JT, Saudek CD, Spark RF, Arky RA (1974) Glucagon induced refractoriness to exogenous mineralcorticoid. J Clin Endocrinol Metab 38: 1147-1149

15. Elrick H, Huffman ER, Hlad Jr CJ, Whipple N, Staub A (1958) Effect of glucagon on renal function in man. J Clin Endocrinol Metab 18: 813-824

16. Pullman T, Lavender AR, Aho I (1967) Direct effect of glucagon on renal hemodynamic and excretion of inorganic ions. Metabolism 16: 358-373

17. Sherwin RS, Hendler R, Felig P (1977) Influence of physiologic hyperglucagonemia on urinary glucose nitrogen and electrolyte excretion in diabetes. Metabolism 26: 53-58

18. Ellis S, Beckett SB (1963) Mechanism of the potassium mobilizing action of epinephrine and glucagon. J Pharmacol Exp Ther 142: 318-326

19. Burton SD, Mondon CE, Ishida T (1967) Dissociation of potassium and glucose efflux in isolated perfused rat liver. Am J Physiol 212: 261-266

20. Glinsmann WH, Mortimore GE (1968) Influence of glucagon and 3', 5' c-AMP on insulin responsiveness of the perfused rat liver. Am J Physiol 215: 553-559

21. Unger RH (1971) Glucagon physiology and pathophysiology. $N$ Engl J Med 285: 443-449

22. Aguilar-Parada E, Eisentraut AM, Unger RH (1969) Effects of starvation on plasma pancreatic glucagon in normal man. Diabetes 18: 717-723

23. Muller WA, Faloona GR, Unger RH (1973) Hyperglucagonemia in diabetic ketoacidosis: its prevalence and significance, Am J Med 54: 52-57

24. Marco J, Diego J, Villanueva ML, Diazfierros M, Valverde I, Segovia JM (1973) Elevated plasma glucagon levels in cirrhosis of the liver. N Engl J Med 289: 1107-1111

25. Bilbrey GL, Faloona GR, White MG, Knockel JP, Borroto J (1974) Hyperglucagonemia of renal failure. J Clin Invest 53: $841-847$

Received: December 6, 1979, and in revised form: June 9, 1980

Prof. F. Massara

Cattedra di Endocrinologia, Ospedale S. G. Battista

Corso Polonia 14

I-10126 Torino, Italy 